\title{
Eucalyptus Oil and Lemon Grass Oil: Effect on Chemical Composition and Shelf-Life of Soft Cheese
}

\author{
M. A. Belewu (Corresponding author) \\ Microbial Biotechnology and Dairy Science Laboratory \\ Department of Animal production \\ University of Ilorin, Nigeria \\ Tel: 234-803-581-7941_E-mail: milkyinka@yahoo.com, mabel@unilorin.edu.ng
}

A. M. Ahmed El-Imam

Department of Microbiology, Faculty of Science

University of Ilorin, Nigeria

K. D. Adeyemi \& S. A. Oladunjoye

Microbial Biotechnology and Dairy Science Laboratory

Department of Animal production

University of Ilorin, Nigeria

Received: November 27, 2011

Accepted: January 26, $2012 \quad$ Published: March 1, 2012

doi:10.5539/enrr.v2n1p114

URL: http://dx.doi.org/10.5539/enrr.v2n1p114

\begin{abstract}
A study was conducted to compare the effect of different levels of Eucalyptus oil (EO) and Lemongrass oil (LO) on the shelf-life of fresh West African soft cheese (wara) in a completely randomized design model for a 28-day period $(\mathrm{n}=60)$. The experiment consists of Treatment A (Control, Cheese kept in the whey), Treatment B (75\% $\mathrm{EO}+25 \%$ LO) and Treatment C (50\% EO + 50\% LO). The results showed similarity in the evaluated parameters (Crude protein, fat and dry matter contents). The ash content was numerically highest in C (5.75\%) and least in A $(5.00 \%)$. The sensory properties were described by positive attributes such as high general acceptability and flavor for Treatments B $>\mathrm{C}>\mathrm{A}$. While the microbial evaluation showed least colony unit for Treatment B followed closely by C and A in that order. In conclusion, while both Eucalyptus oil $75 \%$ plus $25 \%$ lemon grass had a positive impact on the nutritional, sensory and microbial values, whey had no quality to significantly enhance the nutritional, sensory and microbial qualities of West African soft cheese.
\end{abstract}

Keywords: West African soft cheese, Nutritional quality, Microbial values, Eucalyptus oil, Lemongrass oil, Shelf-life

\section{Introduction}

Cheese is one of the commonest dairy products in the world. The nomadic Fulani has, since ancient times, processed milk into a soft cheese known as warankasi (or more commonly Wara) in Nigeria or Woagachi in the Republic of Benin as a means of preserving excess milk. Cheese is a good source of animal protein and is used to replace meat or fish, or in combination with them, in various food recipes. It was originally used to preserve excess milk, but it is now used as a nutrient-dense (such as proteins, lipids, sugars, vitamins and minerals) food (Hildreth, 1977). It is today, a major business worth billions of dollars in many industrialized countries. Indeed, cheeses are now unique products in their own right and cheese-making has advanced beyond being merely a food preservation technique (Aworh, 2008).

Cheese is produced by curdling pasteurized milk on the addition of rennin or rennet at a temperature of $45^{\circ} \mathrm{C}$ (Ihekoronye \& Ngoddy, 1985), while Sodom apple (Calotropis procera) is used in place of rennin in Nigeria. The percentage of water present in cheese and the microorganism used in ripening, and the length of the 
maturing period of the cheese differentiates the many types of cheese present today (Coker et al., 2005). Thus, there are various cheese types (soft cheese e.g. wara, semi-hard cheese e.g. Gouda and hard cheese e.g. Parmesan). There are also un-ripened cheese which is sold immediately after production e.g. cottage cheese, bacteria-ripened cheese which utilizes Brevibacterium linens, and mould-ripened cheeses utilizing a vast array of fungi e.g. Penicillium spp.

Cheese, like milk, is very susceptible to microbial attack depending on the way the milk was produced and handled before, during and after production of the cheese. This could result in spoilage and/or disease. The more commonly implicated organisms are Clostridium tyrobutyricum (Mayer et al., 2010), Pseudomonas fragi, Pseudomonas viscosa, Alcaligenes metalcaligenes, Staphylococcus aureus, and Escherichia coli, (Jenness et al., 1999), S. aureus, Klebsiella spp (Gadaga et al., 2009), Coxiella burnetti, Mycobacterium tuberculosis and Brucella abortus.

Cheese is usually stored in its whey and consumed fresh, but this can only last for 3-5 days (Belewu et al. 2005) after which spoilage occurs. It is sometimes fried and used as a meat-substitute in stews and soups, or smoke-dried to enhance its keeping qualities. However, all these increase its shelf life by only a few extra days or few weeks at best. The capacity to preserve cheese like any other food is directly related to the level of technological development. The slow progress in upgrading traditional food processing and preservation techniques in West Africa contributes to food and nutrition insecurity in the sub-region (Aworh, 2008). Simple, low-cost, traditional food processing techniques are thus essential to not only eradicate starvation and Protein-Energy Malnutrition in the sub-region, but also alleviate poverty by minimizing food wastage and generating income.

Due to the lack of household refrigeration facilities and poor electricity supply in rural areas of Nigeria and other parts of West Africa, several attempts to increase the shelf life of cheese abound. Notable examples include use of antibiotics such as natamycin, and various chemical preservatives such as propionic acid, sodium benzoate, and sorbic acid in the preservation of cheese (Aworh \& Egounlety, 1985; Belewu et al., 2005; Joseph \& Akinyosoye, 1997; Sanni \& Onilude, 1999). Most common methods includefreezing (Alalade, 2007), refrigeration, drying, frying, use of lemon juice as coagulant (Adetunji et al., 2008), and the use of Lemongrass oil (Belewu et al., 2011). Biological methods of preservation are not well elucidated in literature, though there are few reports of some naturally occurring substances shown to have antimicrobial effects in food (Sanwal \& Payasi, 2007; Belewu et al., 2011; Adetunji, 2011). Therefore, the thrust of this study was to evaluate the efficacy of graded levels of Eucalyptus oil and Lemongrass oil in the preservation of soft cheese.

\section{Materials/Methods}

The fact that Eucalyptus oil and Lemongrass oil were found to contain antimicrobial properties, stimulated this experiment with the hope that the antimicrobial properties will help in extending shelf life of cheese which has poor keeping quality. The west African soft cheese was found to undergo spoilage within two to three days of microbial attack.

\subsection{Sample collection}

i. The fresh cheese samples and the whey were purchased from a local market in Ilorin Nigeria.

ii. Eucalyptus plant leaves were collected from trees on the University of Ilorin Campus while Lemongrass was collected from the Senior Staff Quarters of the University of Ilorin Nigeria

\subsection{Preparation of the essential oils}

The leaves collected were air-dried for 24 hours to allow for easy maceration using mortar and pestle. The milled leaves were then soaked in petroleum ether and decanted to get the oil, which was then labeled and stored in dark bottles at room temperature.

\subsection{Experimental treatments}

Treatment A: Whey only- control

Treatment B: $75 \%$ Eucalyptus Oil $+25 \%$ Lemongrass Oil

Treatment C: $50 \%$ Eucalyptus Oil $+50 \%$ Lemongrass Oil

There were 20 cheese samples per treatment and all samples were covered with netting and left on the laboratory bench.

\subsection{Parameters evaluated}

These include nutrient profiling, sensory evaluation, and microbial examination. 


\subsection{Analyses}

The nutrient composition was determined according to the method of the A.O.A.C. (1995). The microbial evaluation was done following the methods of Harringan and McCane (1976), Alexopoulos and Mims (1979) and Belewu and Aina (2000), while a nine-point hedonic scale was used for the sensory evaluation.

All data collected were subjected to analysis of variance using completely randomized design, while means were separated using Duncan (1955) multiple range test.

\section{Results and Discussion}

\section{Microbiological examination}

Microbial growth of up to $\left(8 \times 10^{6} \mathrm{cfu} / \mathrm{ml}\right)$ and foul odour was observed in treatment A before complete spoilage after three days (Table 2). Treatment B had a higher total bacterial count as it was the only treatment that yielded up to two microbial species i.e. Klebsiella pneumoniae $\left(5 \times 10^{2} \mathrm{cfu} / \mathrm{ml}\right)$ and Proteus $s p\left(6 \times 10^{5} \mathrm{cfu} / \mathrm{ml}\right)$. This is in contrast with previous work done which shows LO having a greater antimicrobial activity in wara preservation (Belewu et al., 2011) and may be because of the dilution of the LO with EO which hampered its activity. C with an EO concentration of $50 \%$ had the least count of $7 \times 10^{6} \mathrm{cfu} / \mathrm{ml}$ of $S$. aureus only. B with high amount of LO however inhibited $S$. aureus growth which is in line with Chao et al. (2008) who reported that lemongrass oil inhibited Methicillin Resistant Staphylococcus aureus (MRSA), while Sadlon et al. (2010) also reported inhibition of MRSA by Eucalyptus oil. The presence of Klebsiella pneumoniae and Proteus $s p$ in B could be as a result of contamination during treatment as they were not present in the original sample (control).

\section{Nutrient composition}

There was no statistically significant change in the nutrient profile of the various treatments (Table 1). The dry matter was highest in B (45.15) and least in the control (42.20) which was probably because of the addition of the oils. The dry matter was numerically higher in B than in the others, however there was no significant difference among the treatments. This improvement could be as a result of the higher ratio of EO in B (75\%), than in A or C. Conversely, the crude protein and ash contents of B were slightly lower than in C. The higher ash contents of $\mathrm{B}$ and $\mathrm{C}$ could be as a result of the addition of the oil to the cheese; this is to be expected because these oils have been reported to have hundreds of constituent organic compounds (www.eucalyptusoil.com, 2011). It appears from Table 1 that LO has an anti-nutrient effect on the cheese as B with the higher concentration of LO had lower crude protein and fat content values than A contrary to what was expected, i.e. at least an increased ether extract/fat content on addition of oils. It however had ash content of 5.5, which was higher than in the control 5.0. Treatment $\mathrm{C}$ also showed decreased nutrient profile though not to the extent in $\mathrm{B}$, again this could be because of the lower LO content. The ash content and dry matter contents in B were slightly higher than in the control. However, this could be an attraction for the segment of the population (adults and overweight people), who avoids cheese because it is too nutrient- and energy-dense.

\section{Sensory evaluation}

The most generally accepted sample was Treatment B followed by C and lastly A with 144 points. Additionally, the flavor, texture and taste were significantly $(\mathrm{p}<0.05)$ higher than in Treatment $\mathrm{B}$ (Table 3 ).

A had the best texture and taste while B had the best flavor. Thus for organoleptic improvement, the application of $\mathrm{LO}$ and $\mathrm{EO}$ in equal parts is most desirable. This indicates a potential for the improvement of wara to appeal to a wider market with the attendant improvement in the income of the peasant Fulani who hawk it.

\section{Conclusion}

- The treatments improved the nutrient composition and extended the shelf-life of the cheese to four weeks as against three days for the control which was left in whey.

- Additionally, the application of LO and EO (3:1) significantly improved acceptability among consumers.

- Finally, the simple preservative technology should be encouraged among herdsmen to reduce food insecurity.

\section{References}

Adetunji, V.O. (2011). Effects of Packaging, Treatments, and Storage Conditions on the Survivability of Aerobes and Anaerobes in Vacuum Packaged 'Wara' a Soft White Cheese. Advance Journal of Food Science and Technology, 3(4), 289-293.

Adetunji, V.O., Alonge, R.K., Singh, \& Chen, J. (2008). Production of wara, a West African soft cheese using lemon juice as a coagulant. Journal Food Science and Technology, 41(2), 331-336. 
Alexopoulos, C.J., \& Mims, C.W. (1979). Introductory Mycology (3 ${ }^{\text {rd }}$ edition). New York: Wiley.

Aworh, O.C., \& Egounlety, M. (1985). Preservation of West African soft cheese by chemical treatment. Journal of Dairy Research, 52, 189-195. http://dx.doi.org/10.1017/S0022029900024018

Belewu, M.A., Belewu, K.Y., \& Ganiyu, R.O. (2011). Evaluation of lemon grass (Cymbopogon citrates) oil and pure natural honey on the shelf life of cheese. Electronic Journal of Environmental, Agricultural and Food Chemistry (EJEAFChe), 10(4), 2129-2134

Chao, S., Young, G., Oberg, C., \& Nakaoka, K. (2008). Inhibition of methicillin-resistant Staphylococcus aureus (MRSA) by essential oils. Flavour and Fragrance Journal, 23(6), 444-449. http://dx.doi.org/10.1002/ffj.1904

Coker, J., Crawford, R.A., Johnston, K.A., Singh, H., \& Creamer, L.K. (2005). The Fourth IDF Symposium on Cheese: Ripening, Characterization and Technology. International Dairy Journal, 15, 631-643.

Esser, L. L. (1993). Index of Species Information: Eucalyptus globolus In: Fire Effects Information System, [Online]. U.S. Department of Agriculture, Forest Service, Rocky Mountain Research Station, Fire Sciences Laboratory.

Jenness, R., Wong, N.P., Marth, E.H., \& Keeney, M. (1999). Fundamentals of Dairy Chemistry. United States (Springer). Page 705.

Joseph, J.K., \& Akinyosoye, F.A. (1997). Comparative studies on Red Sorghum Extract and Other chemicals as preservatives for West African soft cheese. International Dairy Journal, 193-198. http://dx.doi.org/10.1016/S0958-6946(96)00051-9

Mayer, M.J., et al. (2010). Genomic sequence and characterisation of the virulent 1 bacteriophage ФСТР1 from Clostridium tyrobutyricum and heterologous expression of its endolysin. Applied Journal of Environment and Microbiology. http://dx.doi.org/10.1128/AEM.0098

Santos SA et al. (2011). Characterization of phenolic components in polar extracts of Eucalyptus globulus Labill. bark by High-Performance Liquid Chromatography-Mass Spectrometry. Journal of Agric and Food Chemistry. 59(17), 9386-9393.

Singh, H.P., Mittal, S., \& Kaul, S. (2009). Characterization and anti-oxidant activity of essential oils from fresh and decaying leaves of Eucalyptus tereticornis. Journal of Agric and Food Chemistry, 57, 6962-6966. http://dx.doi.org/10.1021/jf9012407

Sadlon, A.E., \& Lamson, D. (2010). Immune-modifying and antimicrobial effects of Eucalyptus oil and simple inhalation devices. Alternative medicine review, 15(1), page 3.

Sanni, A.I., Onilude, A.A., Ogunbanwo, S.T., \& Smith, S.I. (1999). Antagonistic activity of bacteriocin produced by Lactobacillus species from ogi, an indigenous fermented food. Journal of Basic Microbiology. 39, 189-195. http://dx.doi.org/10.1002/(SICI)1521-4028(199906)39:3<189::AID-JOBM189>3.0.CO;2-R

Sanwal, G. G., \& Payasi, A. (2007). Garlic extract plus sodium metabisulphite enhances shelf life of ripe banana fruit. International Journal of Food Science \& Technology, 42(3), 303-311. http://dx.doi.org/10.1111/j.1365-2621.2006.01222.x

Table 1. Chemical evaluation of treated and untreated cheese samples*

\begin{tabular}{|c|c|c|c|c|}
\hline Parameter & A (Control) & $\mathbf{B ~ ( 7 5 \% : 2 5 \% )}$ & $\mathbf{C ~ ( 5 0 \% : 5 0 \% )}$ & \pm SEM \\
\hline Dry matter & 42.20 & 45.15 & 42.50 & $12.21^{\mathrm{NS}}$ \\
\hline Crude protein & 39.10 & 29.97 & 34.82 & $11.39^{\mathrm{NS}}$ \\
\hline Ether extract & 88.50 & 83.00 & 83.75 & $25.57^{\mathrm{NS}}$ \\
\hline Ash & 5.00 & 5.50 & 5.75 & $1.79^{\mathrm{NS}}$ \\
\hline
\end{tabular}

* Mean of four determinations

Table 2. Microbial evaluation of treated and untreated cheese samples ${ }^{*}$

\begin{tabular}{|c|c|c|c|c|}
\hline Parameter & A (Control) & B (75\%:25\%) & C (50\%:50\%) & \pm SEM \\
\hline Colony forming units & $8 \times 10^{6}$ & $6 \times 10^{6}$ & $7 \times 10^{6}$ & \\
\hline
\end{tabular}


Table 3. Sensory evaluation of treated and untreated cheese samples

\begin{tabular}{|c|c|c|c|c|}
\hline Parameter & A (Control) & $\mathbf{B} \mathbf{( 7 5 \% : 2 5 \% )}$ & $\mathbf{C ~ ( 5 0 \% : 5 0 \% )}$ & 土SEM \\
\hline General acceptability & $*^{\mathbf{2}} 144.00^{\mathrm{a}}$ & 181.00 & $154.00^{\mathrm{a}}$ & 27.81 \\
\hline Flavor & 124.00 & $179.75^{\mathrm{a}}$ & $170.25^{\mathrm{a}}$ & 21.66 \\
\hline Texture & $190.00^{\mathrm{a}}$ & $181.00^{\mathrm{a}}$ & 167.57 & 30.04 \\
\hline Taste & 167.00 & $154.50^{\mathrm{a}}$ & $142.40^{\mathrm{a}}$ & 28.55 \\
\hline
\end{tabular}

*values on the same row with the same superscript are not significantly different from each other 